\author{
Ilija Stevanović \\ Research Assistant \\ University of Belgrade \\ Institute Mihailo Pupin \\ Boško Rašuo \\ Full Professor \\ University of Belgrade \\ Faculty of Mechanical Engineering
}

\section{Development Of a Miniature Robot Based on Experience Inspired by Nature}

\begin{abstract}
The paper explains the fundamentals of bionics. Using the basic principles of bionics, an analysis was made of the movement of legged biological systems on the basis of laboratory observations and measurements, in which they studied the movement of biological systems moving with the help of its legs. Then the 3D model of the robot is designed inspired with insects with six legs and using two of the four basic principles of movement with the help of legs. $3 D$ model was created with the of Solidworks software package. A mathematical model with Matlab Simulink - SimMechanic Software. Using modern software tools like Solidworks and Matlab Simulink a mathematical analysis of its mechanism for movement in a $3 D$ environment is performed. It is shown that the Bionics with the help of modern software engineering can be a powerful tool, but to get complete results it is necessary to apply all the principles that is obtained by the analysis.
\end{abstract}

Keyword : design, Bionics, SolidWorks, Matlab Simulink, micro-robot

\section{INTRODUCTION}

Solutions that nature created by the evolution for its biological systems or eco-systems are usually the most economical, the most intelligent and the closest to the ideal for given conditions in which they are incurred. They are valuable and inexhaustible source of knowledge for development of new, innovative and advanced technical systems. Faced with the challenges and problems that we have in current industrial "development and progress", in terms of irrational energy consumption, increasing environmental pollution, waste accumulation and extinction of many different kinds of species, in order of our survival man is forced to develop new products, solutions seeking inspiration in nature [1,2].

The paper defines a complete methodology for the design of miniature robot which included bionic principles. It is also shown the analysis of the necessary biomechanical peculiarities of movement that miniature robot that moves with legs on different terrains should possess.

It is sketched and 3D modeled mini-robot and all of its necessary components of the mechanism to move in a 3D environment using modern software packages (Autodesk 3ds Max, SolidWorks), and then formed a mathematical model of movement of individual components of the robot in the software package Matlab - Simulink (Sim Mechanics). Animation, simulation and dynamic analysis of the mechanism of the mini-robot are presented in this paper.

\section{BIONICS}

Bionics is the application of biological methods and

Received: October 2014, Accepted: October 2015, Correspondence to: Ilija Stevanović, University of Belgrade, Institute Mihailo Pupin, Volgina 15, 11060, Belgrade, Serbia,

E-mail: ilija.stevanovic@pupin.rs

doi:10.5937/fmet1701189S

(C) Faculty of Mechanical Engineering, Belgrade. All rights reserved systems found in nature to the study and design of engineering systems and modern technology.

To deal with the technical biology means to explore and describe the nature from the basic technical sciences, and physics point of view. Research of this kind lead to exceeding the boundaries between different scientific disciplines. Technical biology knows no boundaries and it just "existing" from exceeding those limits $[3,4]$.

Biological bionics is using knowledge of botany, zoology, medicine gathered by observing functioning of a living organisms, to extract those principles, to establish a vital link to the technical problem which has to be solved.

The next step is the mathematical treatment of this biological content, the so-called biological modeling, where mathematical models accurately mapped the processes of living organisms that are for a given technical issue of particular importance.

In any case, it should be noted that there are some existence of similarities between the positions of the nature in the "design" of biological solutions for their living prototypes and actual designing from engineering point of view. Common to them is primarily the universal striving for the most frugal and the most economical concept - in the first case in the sense that greater energy savings, and the second in terms of the lowest prices.

The essence of a bionic approach lies in the fact that designers, planners, engineers and designers, or people who are responsible for innovation constantly remind themselves that the nature in the introduction of its new "techniques" for their prototypes does not cause any, or possibly minimal harm to the environment, such and that the real solutions must be found in it. [5,6]

\subsection{Legged robots}

Nowadays it may seem that there is already a lot of different ways to move the robots on land, for example, 
the vehicles with wheels and caterpillars, which are capable of moving at high speeds and therefore not need to examine the motion with the help of legs as an alternative.

On the other hand it must be noted that the performance of traditional mobile robots largely depend on the nature of the environment in which they move. In fact, about half of the land area is inaccessible for such vehicles. The mobile robots, through inaccessible - with many sharp edges and unstable terrain require machines that can move with legs. Although for many applications traditional mobile platforms with wheels provide satisfactory fulfillment of the set requirements in terms of robustness and energy efficiency, in the long run systems that are able to operate in a wide variety of terrain conditions will be robots that have legs.

In the process of designing legged robots it is necessary to find a compromise between freedom of movement on one side and a decrease of reliability due to the increased number of actuators for the movement on the other side. If the system is too complex then it creates the problem of control, because with today's software and hardware it has not yet been possible to provide sufficient bandwidth of control signals if we want for the robot move at higher speeds.

Also, an important aspect of additional features of legged robots is Intelligent Mobile Robot Navigation in unstructured environment as for every mobile robot platform exists obstacle that cannot be cross over but go around [7].

The research was carried out on the movement of different biological systems, which have legs. By observing it is attempted to define some general principles that are necessary for this task.

Insects are a good example of versatile legged motion and they have a very large number of degrees of freedom in their leg joints, a very large number of muscles and a large number of neurons for control. Simply copying of such systems nowadays is practically impossible. Instead, an attempt was made to understand the basic principles that allow such movement.

\subsection{Analysis of the motion of legged biological systems and conclusions.}

What was done in the laboratory observations is that in addition to the recording of the leg contacts sequence to the ground during the motion of various biological systems it is also taking measure of the contact force with which the objects that are moving with leg acting on the surface. In doing so, they spotted the four basic principles:

1. The control mechanism for the movement is built into the mechanism to move. So the mechanism for motion has self-adaptation to the environment. This was achieved by designing it correctly. In this way the problem of movement over rough terrain greatly simplified. To an insect moving through unknown and uneven terrain only need to choose the direction and speed at which it wants to move. Legs do everything on their 'own' by their design. They did not need any special sensors on them, nor any special control of the leg in order to achieve this.[8];

2. Depending on the number of legs and walking speed they are using different types of walking gates and foot schedules during each step while moving. (Fig.1)[8];

3. It is concluded by measuring the force on which objects that are moving acting on the surface, is that they are basically all behave as if their entire mass is jumping on a stick with a spring, (Fig.2)[8];

4. It is not only that the vertical plane is it in which it is possible pogo stick like bouncing from the ground. It has been observed that it happened in a horizontal plane also. The system behaves as if the body is connected to the rod with spring and damper in the horizontal plane (Fig.3)[9].

\section{Spring-Mass Systems}

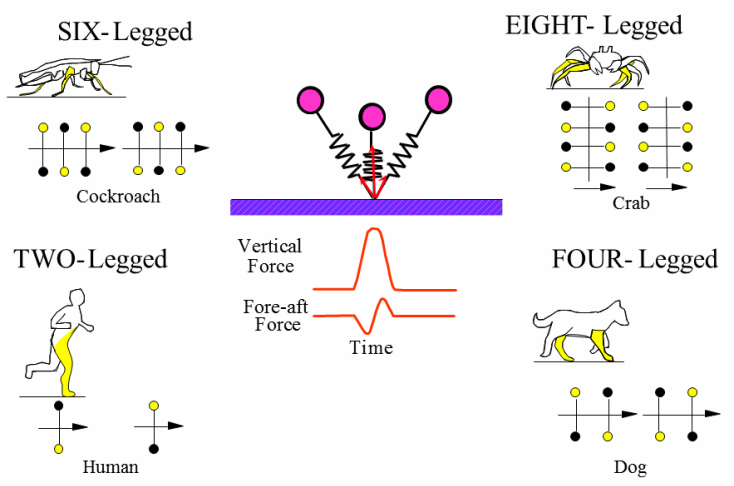

Figure 1. Different walking gates of motion of legged systems [2]

\section{Leg as Spring \& Damper}

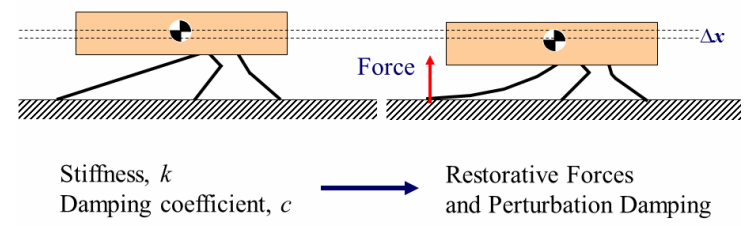

For an Oscillating System:

Force $=$ force due to + force due to + force due to mass stiffness damping

$$
\text { Force }=k \mathbf{x}+c \dot{\mathbf{x}}+m \ddot{\mathbf{x}}
$$

Figure 2. Analysis of the insect body as oscillatory system in vertical plane [2]

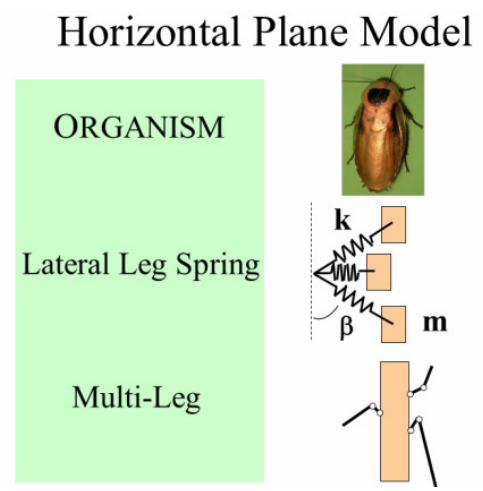

Figure 3. Analysis of the insect body as oscillatory system in horizontal plane [9] 


\section{CREATING MODEL IN SOLIDWORKS}

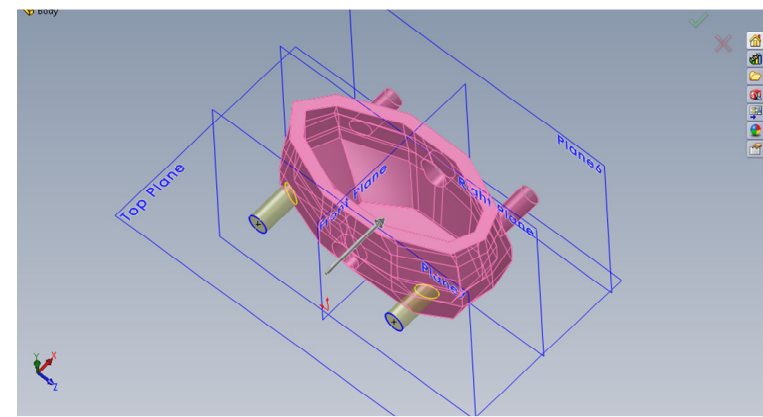

Figure 4. Creating robot body

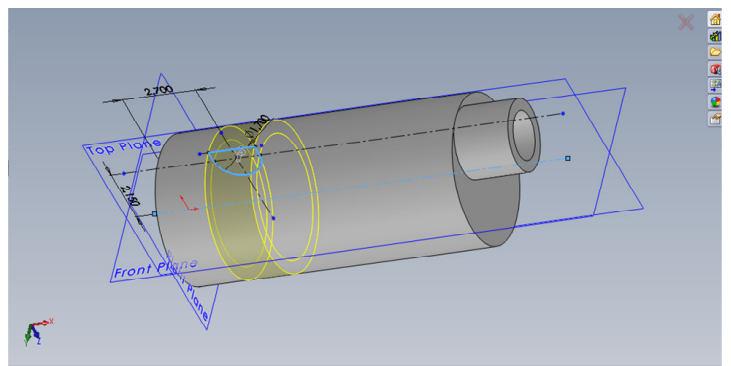

Figure 5. Creating drive cam rotor-2

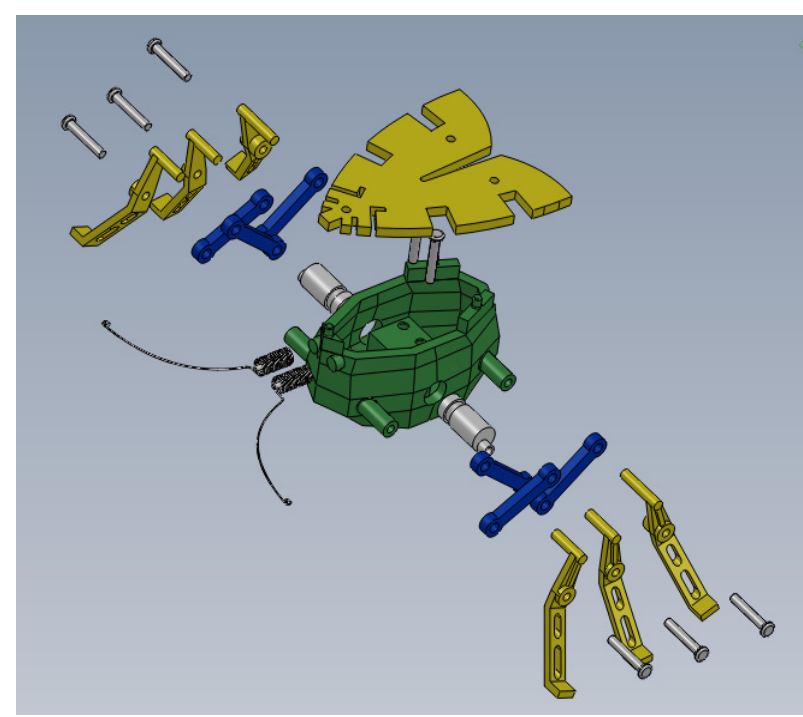

Figure 6. All components of robot mechanism

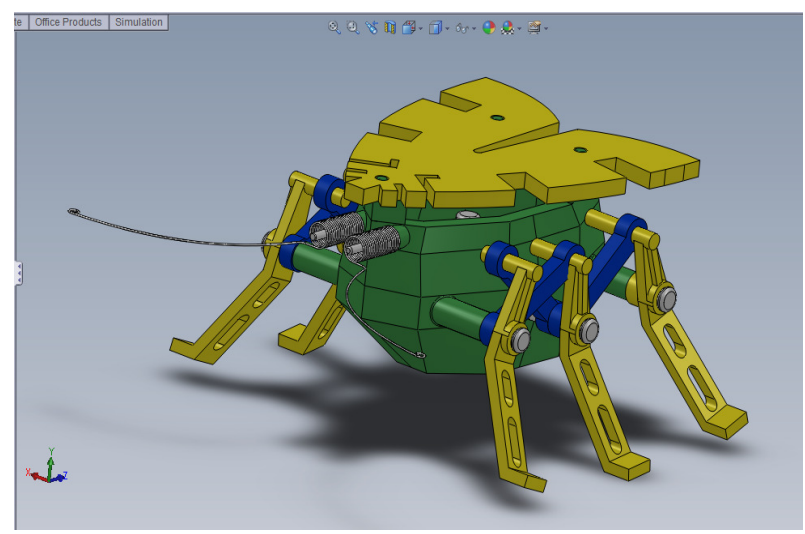

Figure 7. Look of assembled robot

\section{CREATING ROBOT MATHEMATICAL MODEL}

Nature designed millions of living species during millions of years. Those attempts in the design that are not successful are now in the archaeological museum as extinct species. To demonstrate that a design is or is not successful nature has time - a lot of time, from our point of view, and virtually limitless resources - nothing goes to waste thanks to recycling. Everything works according to the principle "trial and error". So a small change to the existing design of the living being and its setting in the environment to verify that the design is a good addition to the indispensable component of time and resources spent on its creation. This is the model of how the evolution of life works.

What the engineers are trying to achieve when designing machines that will be inspired by nature is to try to understand the principles by which nature has come through a number of iterations of life cycle of every living being. It may happen that the constructor is not well understand the principle or is it well understood or not well applied. And in the first and in the second case, the result will be a poorly designed product.

We need to find a way to examine the quality of our designs before it is actually made. The complete process is explained in [10]. Presented in [11] and published in [12].

In order to reduce the time we need to gofrom conceptual design to finished product in the design process and before making a prototype it is necessary to visualize the working model in CAD programs do a complete analysis of the mechanisms that we have designed.

The next step in the project of mini-robot with six legs is the creation of the mathematical model. For this we need to know all the physical geometrical characteristics of individual components and their connections with other parts of the robot mechanism.

What we need to know to define each individual component of a rigid body in a mathematical model of the robot is its mass - $\mathrm{m}$, inertia tensor - I, and the position of the CG - center of gravity, its coordinates and direction of axes which pass through it. We also have to define the initial positions of each component of mechanism, and their connections with other parts of the robot.

The inertia or moment of inertia tensor of an extended rigid body describes its internal mass distribution and the body's angular acceleration in response to an applied torque.

Let $\mathrm{V}$ be the body's volume and $\rho(\mathrm{r})$ its mass density, a function of vector position $r$ within the body. Then the components of the inertia tensor $I$ are:

$$
I_{i j}=\int_{V} d V\left[\delta_{i j}|r|^{2}-r_{i} r_{j}\right] \rho(r)
$$

The indices $i, j$ range over $1,2,3$, or $\mathrm{x}, \mathrm{y}, \mathrm{z}$. This tensor is a real, symmetric 3-by-3 matrix or equivalent MATLAB $®$ expression.

The inertia tensor of a Simscape Multibody body is always evaluated in that body's center of gravity coordinate system (CG (center of gravity) CS (coordinate system)). That is, the origin is set to the body's CG and the coordinate axes are the CG CS axes.

Because the CG CS of a Body block is fixed rigidly in the body during simulation, the values of the inertia tensor components do not change as the body rotates. 
The mass is the proportionality between a force on a body and the resulting translational acceleration of that body.

Let $\mathrm{V}$ be the body's volume and $\rho(\mathrm{r})$ its mass density, a function of position $r$ within the body. Then the mass $\mathrm{m}$ is:

$$
m=\int_{V} d V \rho(r)
$$

SimMechanics is based on Simscape, the platform product for the Simulink physical modeling family, encompassing the modeling and design of systems according to basic physical principles. Simscape runs within the Simulink environment and interfaces seamlessly with the rest of Simulink and with MATLAB.

For each component of the mechanism it is necessary to define the physical and geometrical characteristics. Also, the relative position and orientation in space, and their connections. When all the necessary data is collected, it must be, in a certain form import to MATLAB.

Table 1. Physical and geometrical characteristics of drive cam rotor-2

\begin{tabular}{|l|c|}
\hline Name & Value \\
\hline Volume & \multicolumn{2}{|c|}{$2.01093 \mathrm{e}-007\left(\mathrm{~m}^{3}\right)$} \\
\hline Density & \multicolumn{2}{|c|}{$1000\left(\mathrm{~kg} / \mathrm{m}^{3}\right)$} \\
\hline Surface & \multicolumn{2}{|c|}{$0.00029326\left(\mathrm{~m}^{2}\right)$} \\
\hline Mass & $0.000201093(\mathrm{~kg})$ \\
\hline $\begin{array}{l}\text { Moment of } \\
\text { inertia } \\
\text { tensor of } \\
\text { the drive } \\
\text { cam rotor-2 }\end{array}$ & $\left.\begin{array}{ccc}6.67147 \mathrm{e}-010 & 0 & 4.15464 \mathrm{e}-012 \\
0 & 0,2.56235 \mathrm{e}-009 & 0 \\
4.15464 \mathrm{e}-012 & 0 & 2.57819 \mathrm{e}-009\end{array}\right]$ \\
\hline
\end{tabular}

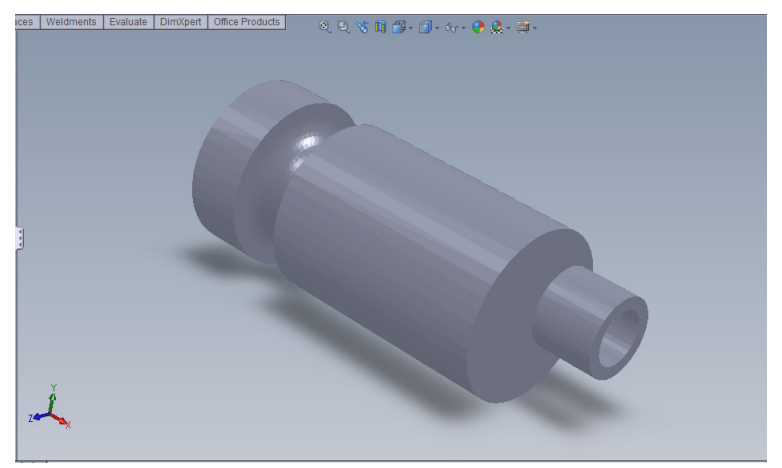

Figure 8. STL file of 3D model of drive cam rotor-2

Based on these data, XML file is generated. Part of the code which relates to basic information about the robots drive cam rotor- 2 is in Table 2.

STL files are generated based on the created 3D model of robot in the SolidWorks application. Example on (Fig.8) STL files we use to facilitate consideration of mutual relations and the movement of certain components in the mathematical model of the robot, and then based on XML and STL files from Matlab program generate a block diagram of a mathematical model of the entire robot mechanism (Fig.9). Any physical component of the mechanism is presented in the robot mathematical model diagram, with the "Body block" and each such solid body block characteristics can be change if needed.

Table 2. Part of the code of XML file relating to the geometrical characteristics of the drive cam rotor-2

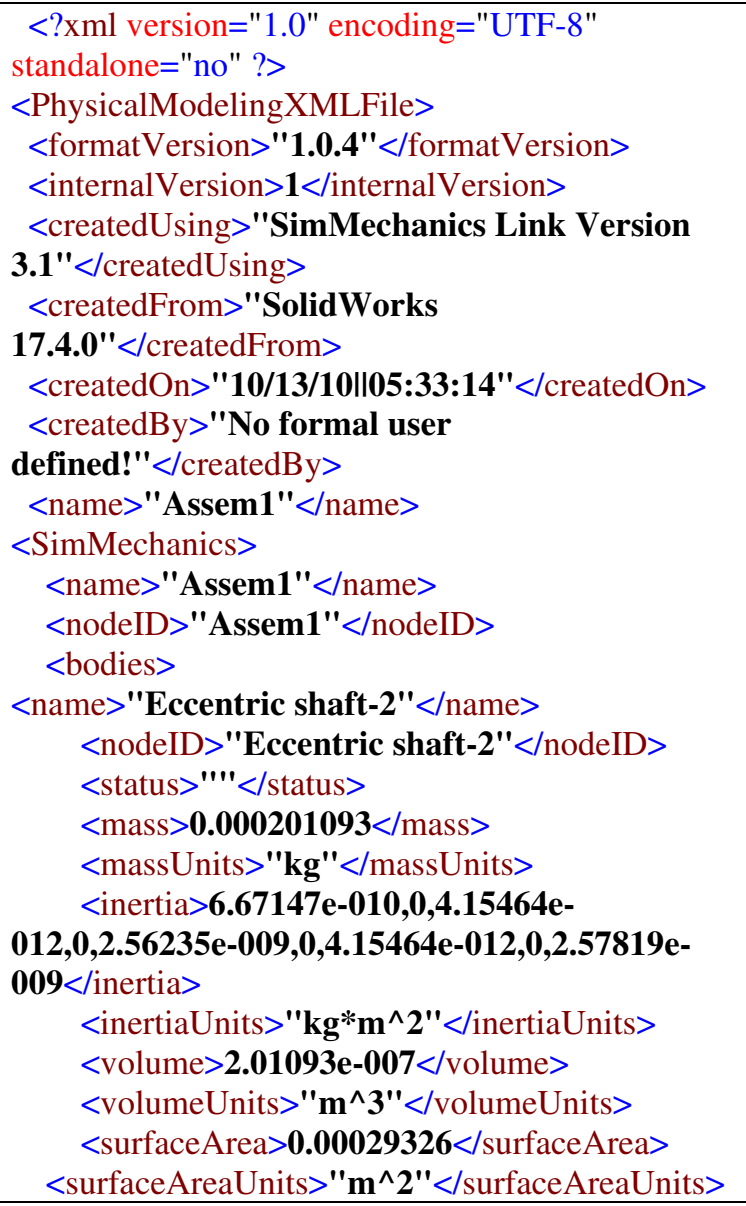

\section{ANALYSIS OF MATHEMATICAL MODEL OF ROBOT}

In this study, two analyses are performed. The first is when the robot body is fixed in space. This means that the robot legs do not touch the walking surface. In this case, all recorded parameters originate only from the fact of constant torque on the drive cam rotor of robot.

The second analysis was performed with a robot that can freely move in space. Gravity acts on it, under whose influence it free-falls to the ground and detect force at the time and place of contact of the foot with the ground. The friction foot with the ground was not taken into account. On drive cam rotors are applied constant torque of $0.000007[\mathrm{~N} * \mathrm{~m}]$.

\subsection{Analysis - Procedure}

The analysis is done in a way that desired torque is applied to the drive shaft of the mechanism and then put sensors on point of interests. We have a choice between the sensors that are placed on the linkage between the bodies to measure the reactions and those which are placed on the body itself which is measure motion of certain points of the body in space.

After running the simulation window opens with a visual representation of the model. 


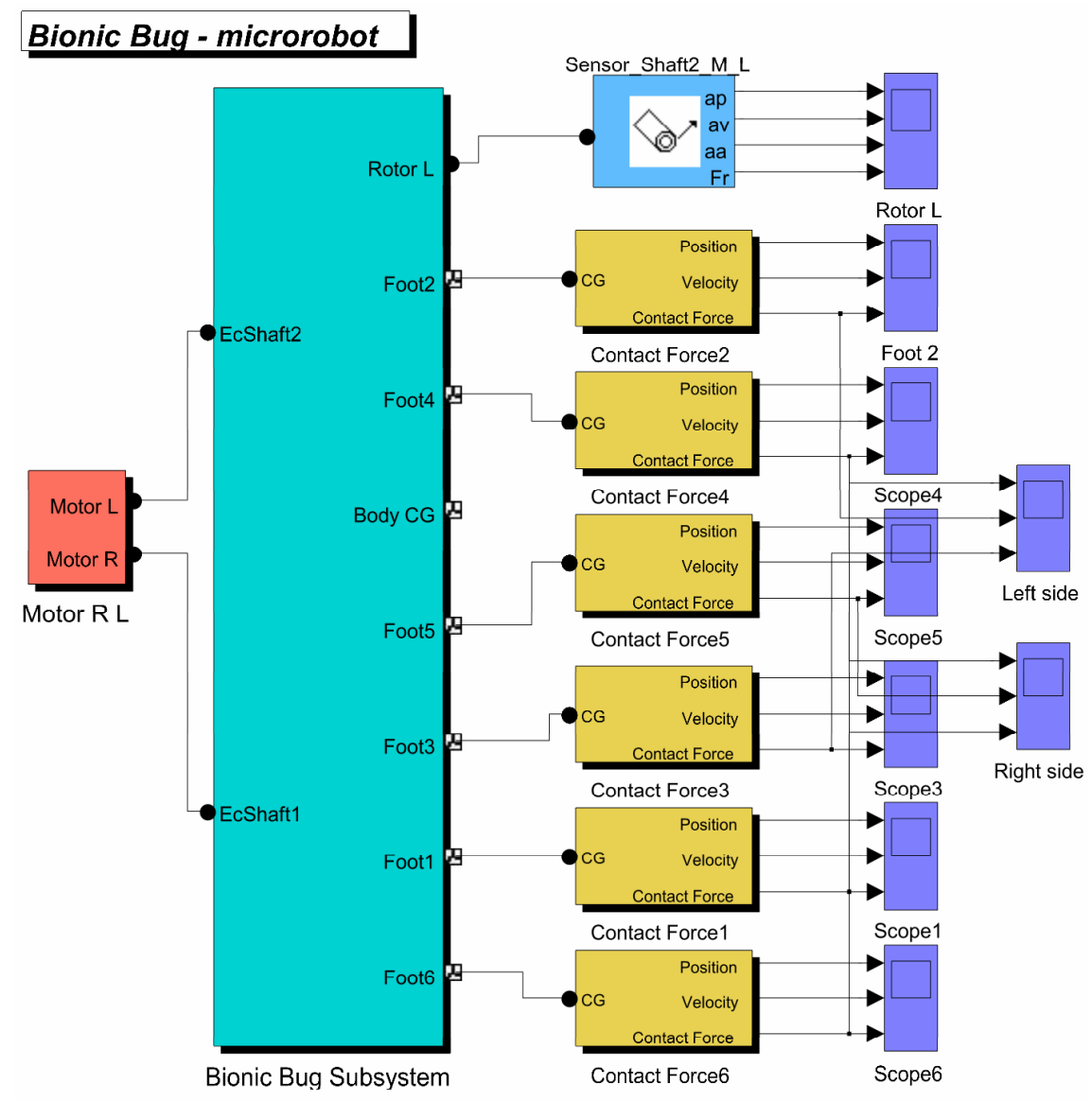

Figure 9 a. Block diagram of the mathematical model of the robot

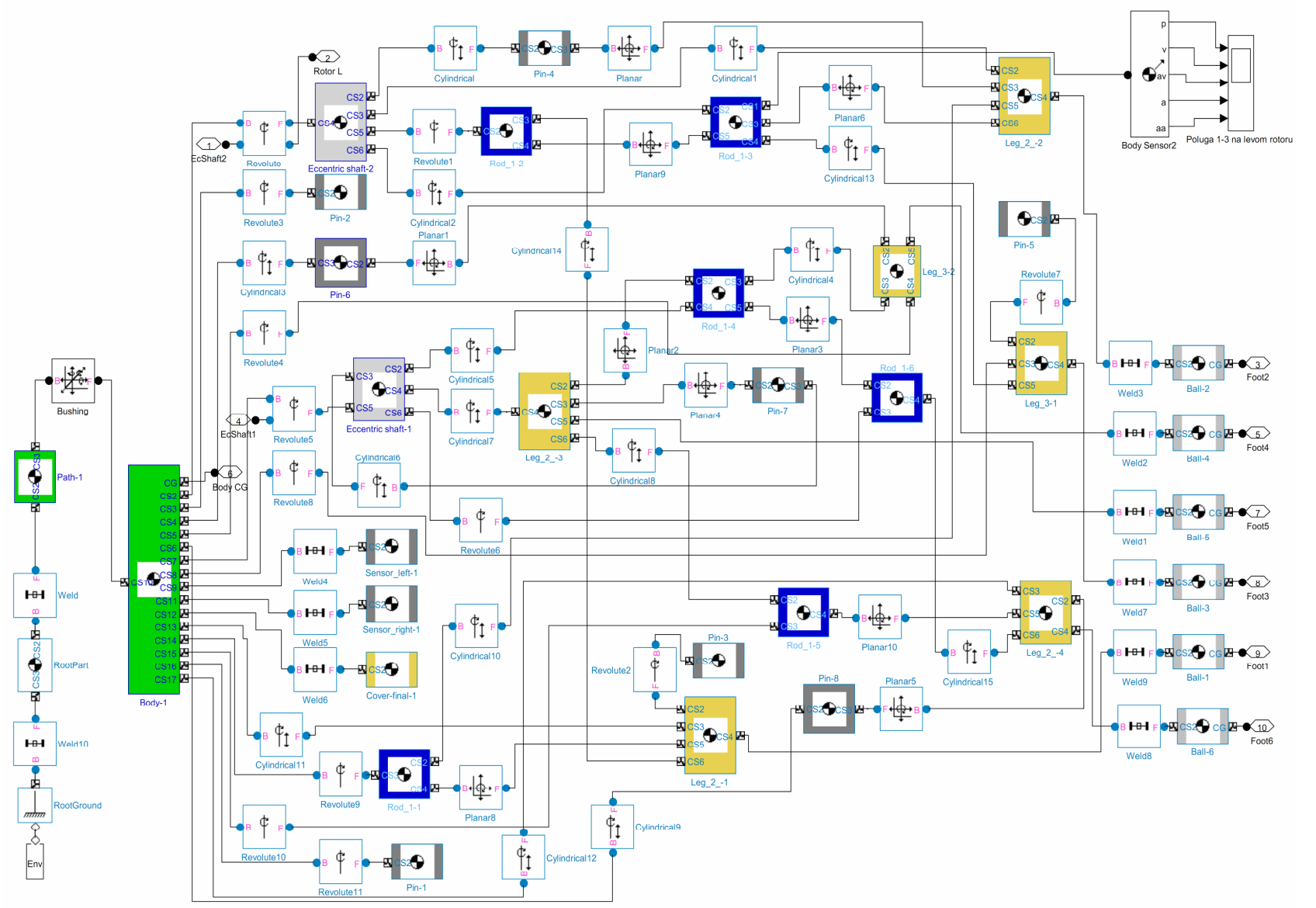

Figure $9 \mathrm{~b}$. The main subsystem diagram of the mathematical model of the robot 
The window with the readings from the sensors that were set on the housings of the drive cam rotor- 2 can be seen. (Fig.13)

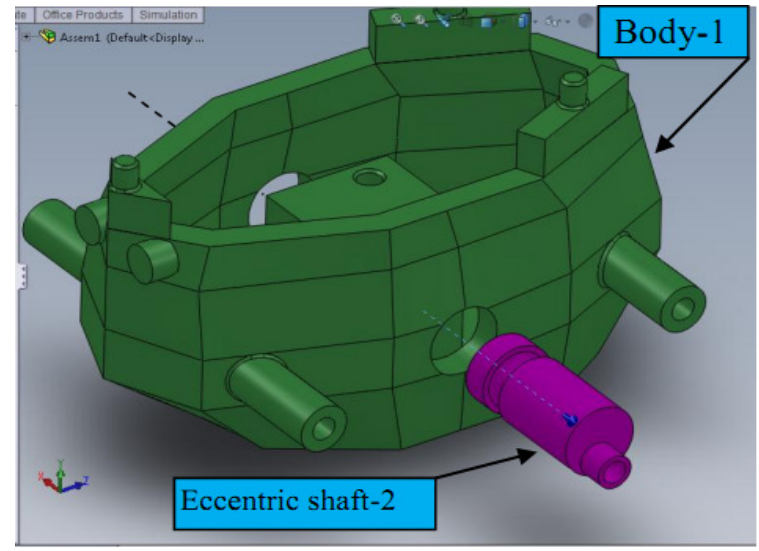

Figure 10. The bodies that are connected with block Revolute 6 in the mathematical model of the robot

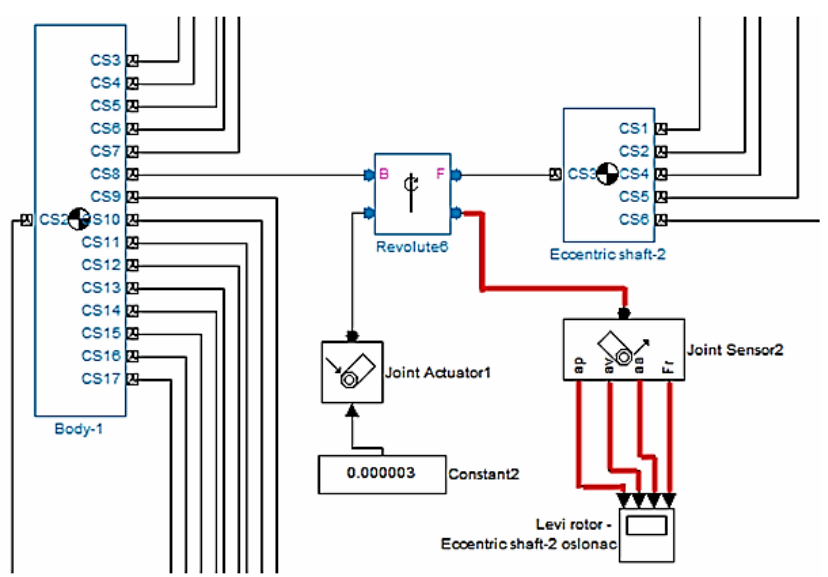

Figure 11. Simulink - part of a block diagram of a mathematical model of the robot with the present body of the robot and actuators with sensors mounted on the eccentric shaft -2 bearings (Fig.10)

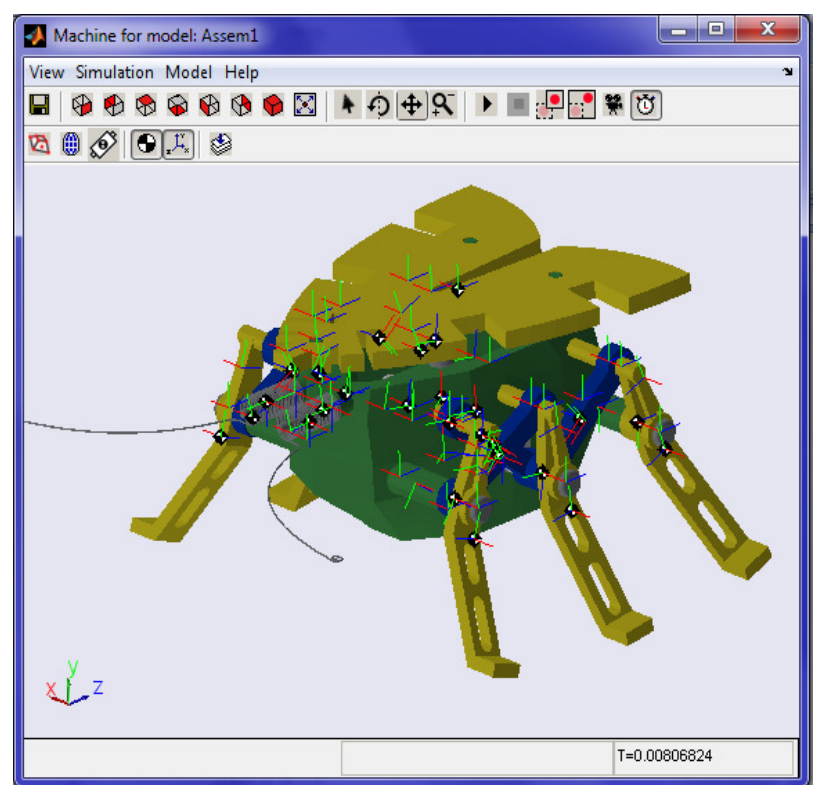

Figure 12. Simulink window with a visual presentation of a mathematical model of the robot

With the help of Body Sensor 2 block that can be set to any component of the mechanism of the robot are measured values from Table 3 .
In this case the sensor is placed on the body Rod_13 (Fig.14) as shown in (Fig.15) in the desired coordinates of the body.

Table 2. The measurements that we perform with the help of Joint Sensor

\begin{tabular}{|l|c|}
\hline Angle & {$[\mathrm{rad}]$} \\
\hline Angular velocity & {$[\mathrm{rad} / \mathrm{s}]$} \\
\hline Angular acceleration & {$\left[\mathrm{rad} / \mathrm{s}^{\wedge} 2\right]$} \\
\hline Reaction force & {$[\mathrm{N}]$} \\
\hline
\end{tabular}

Table 3. Body sensor measurements

\begin{tabular}{|l|c|}
\hline Position & {$[\mathrm{m}]$} \\
\hline Velocity & {$[\mathrm{m} / \mathrm{s}]$} \\
\hline Angular velocity & {$[\mathrm{rad} / \mathrm{s}]$} \\
\hline Acceleration & {$\left[\mathrm{m} / \mathrm{s}^{\wedge} 2\right]$} \\
\hline Angular acceleration & {$\left[\mathrm{rad} / \mathrm{s}^{\wedge} 2\right]$} \\
\hline
\end{tabular}

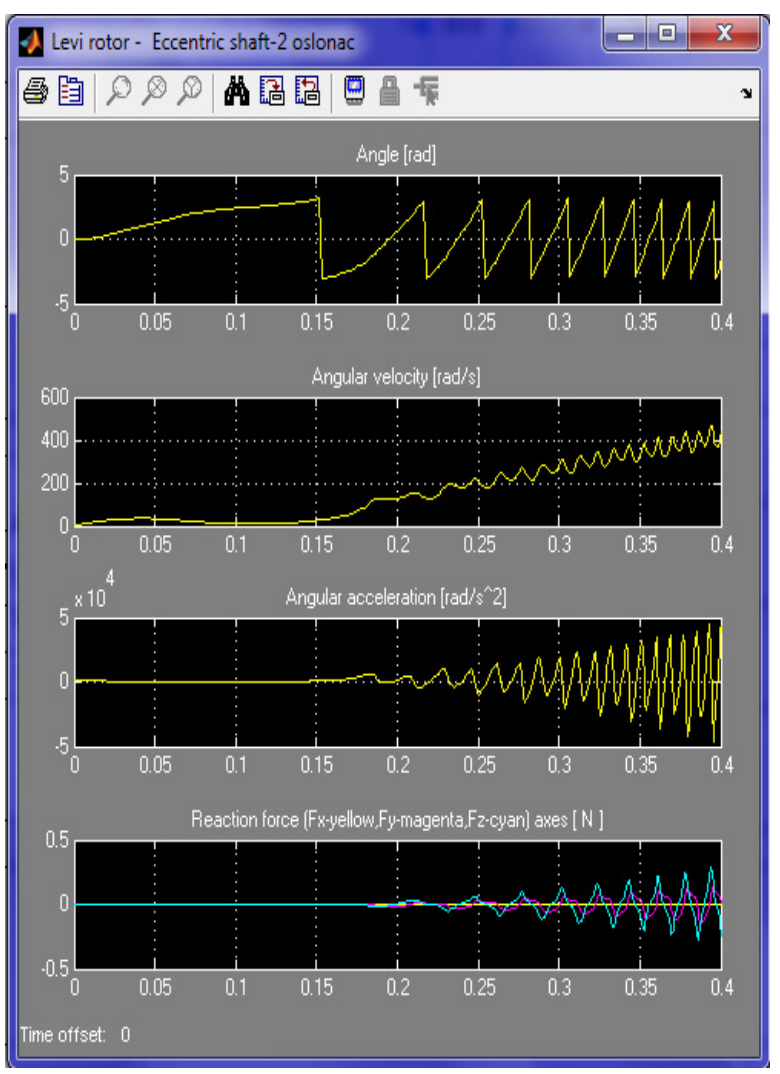

Figure 13. Showing the value read by the sensor on the left drive cam rotor housings applied with constant torque of $0.000003\left[\mathrm{~N}^{\star} \mathrm{m}\right]$

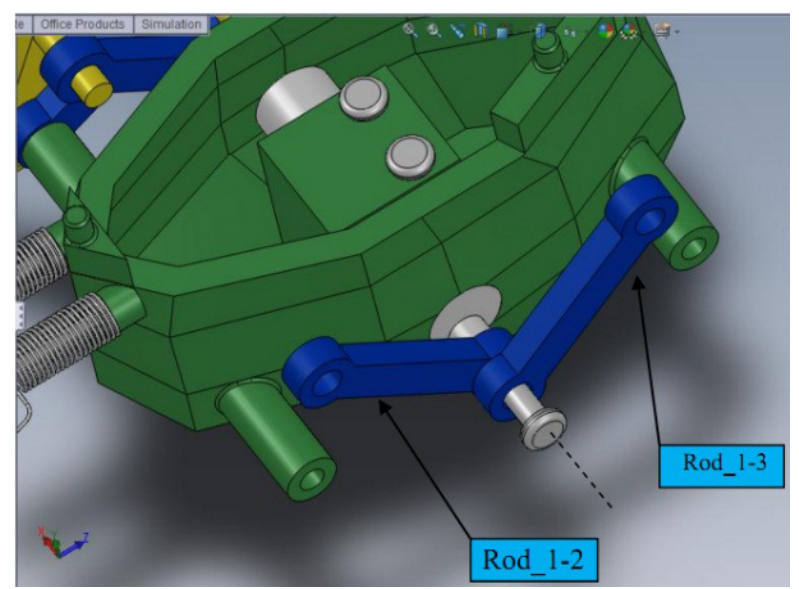

Figure 14. Body sensor on Rod_1-3 


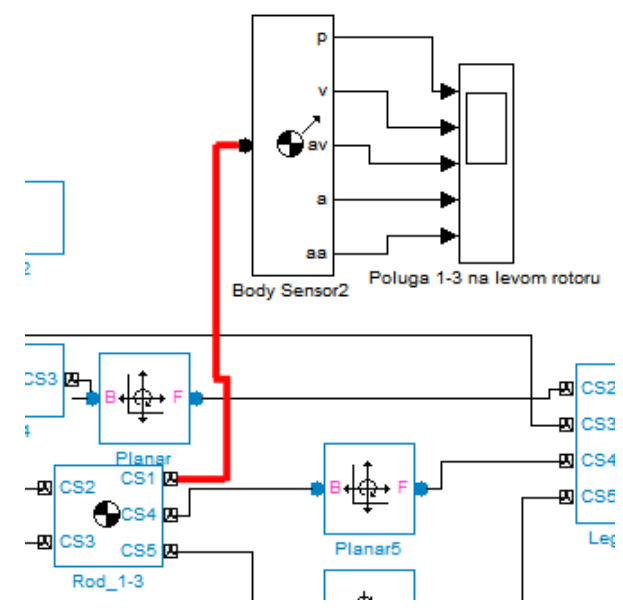

Figure 15. Simulink - part of a block diagram of a mathematical model of the robot with the presented body of the robot with sensors placed on the Rod_1-3 body (Fig.14)

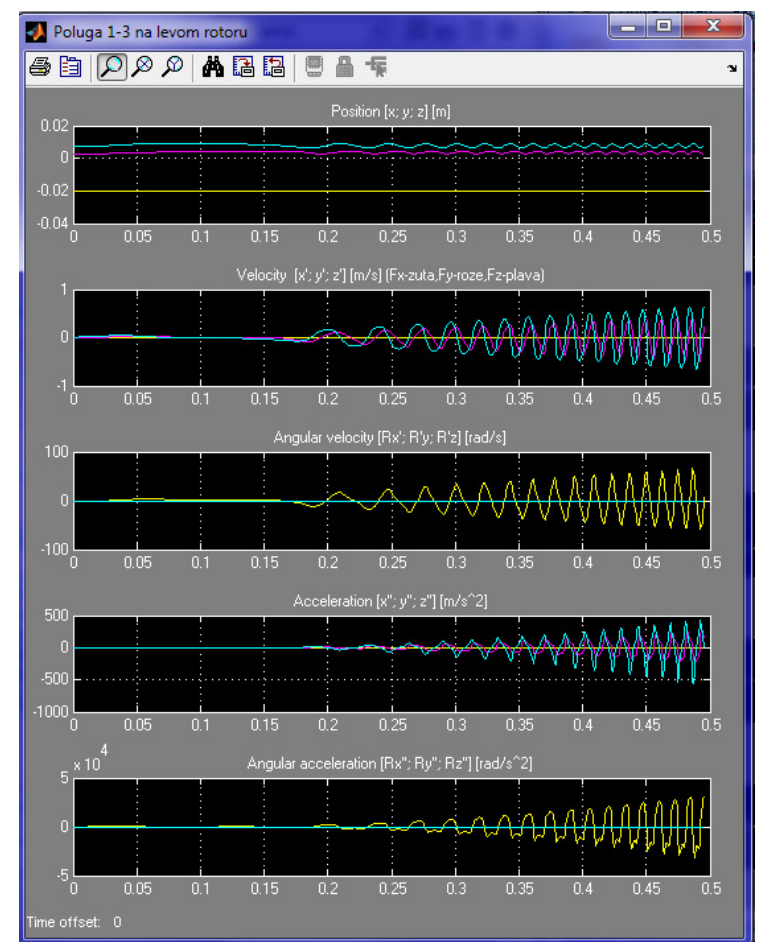

Figure 16. Showing the values from the sensor on the Rod_1-3 (Fig.14) (Fig.15)

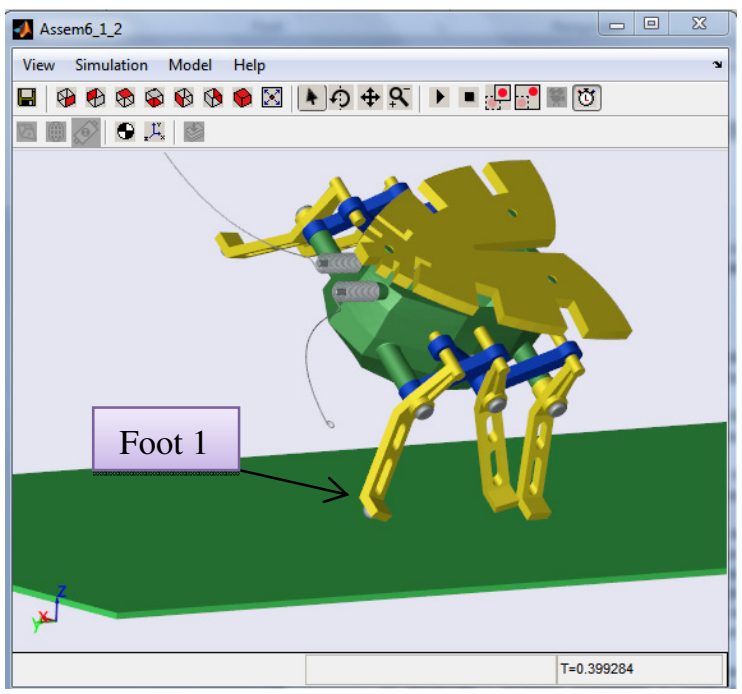

Figure 17. Simulink window with a visual presentation of a mathematical model of the robot, analysis 2

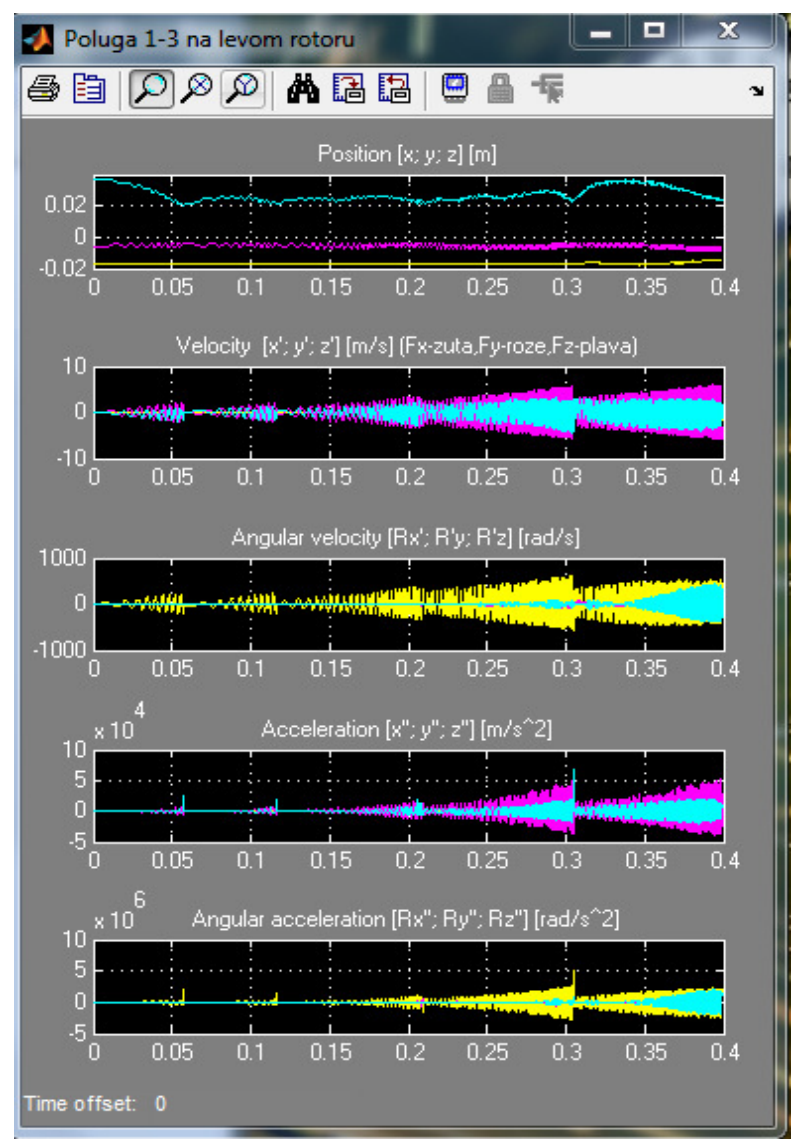

Figure 18. Showing the values from the sensor on the Rod_1-3 (Fig.14) (Fig.15) analysis 2.

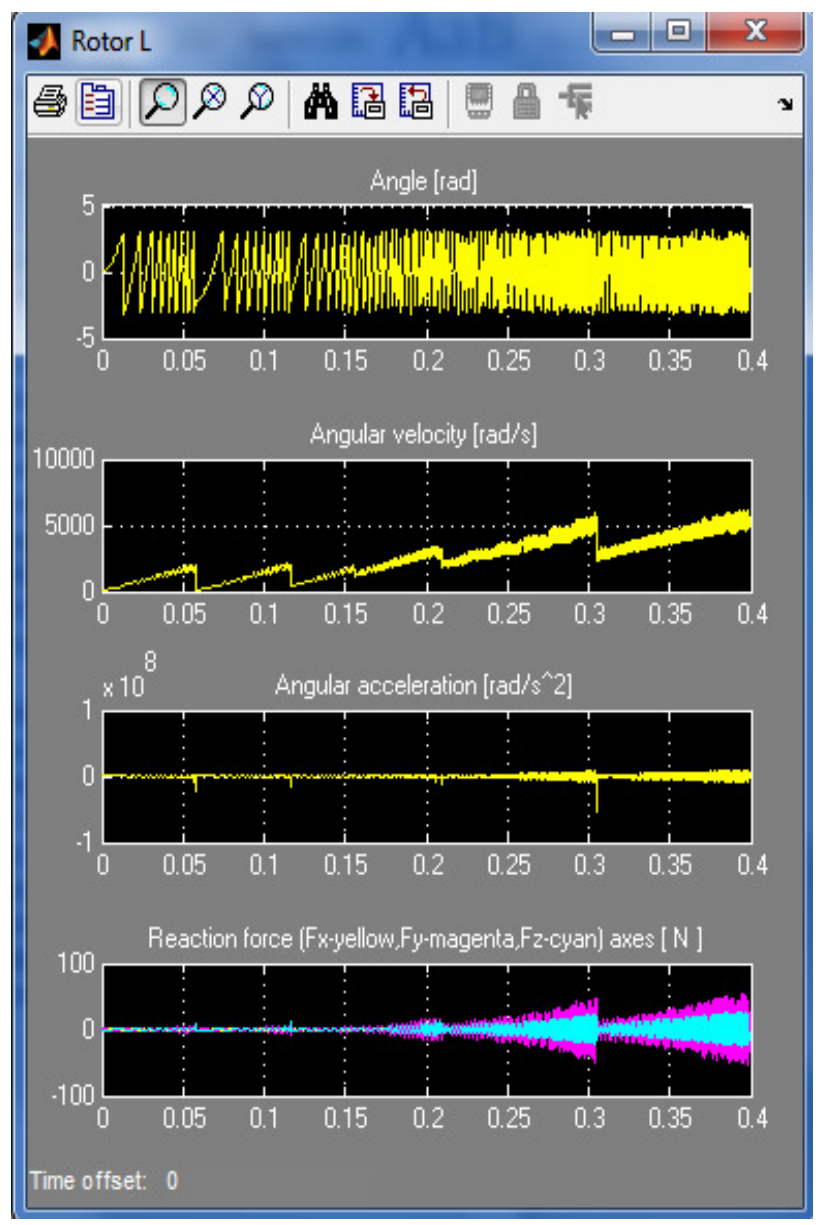

Figure 19. Showing the values from the sensor on the left drive cam rotor housings, analysis 2 


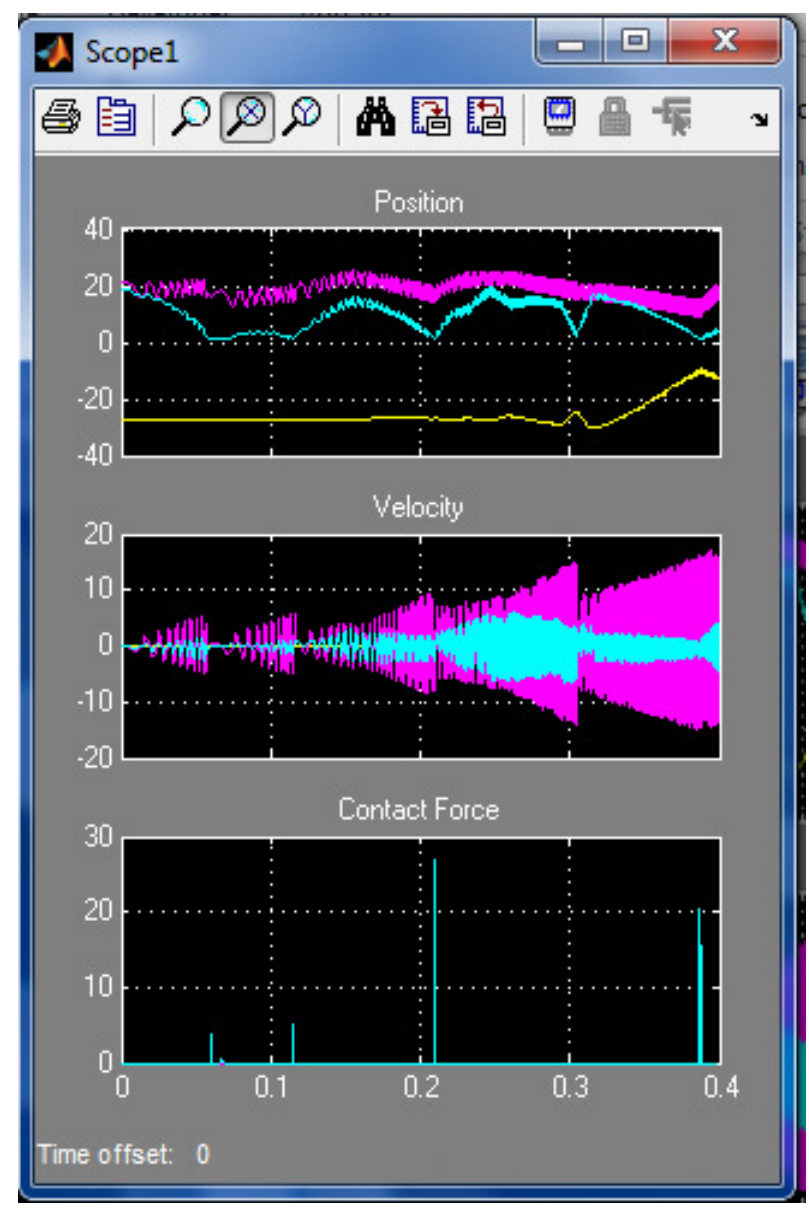

Figure 20. Showing the values from the sensor on the foot 1 of Figure 17, the analysis of 2

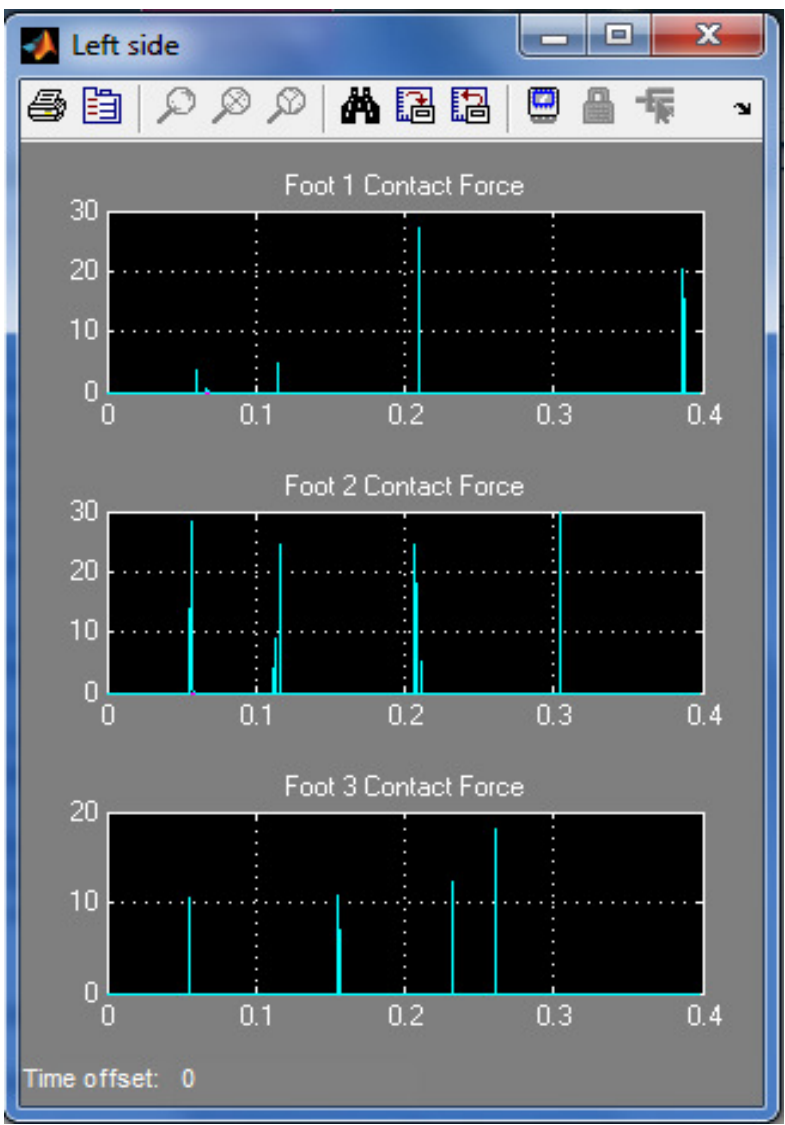

Figure 20. Showing the values from the sensor on the feet 12 and 3 on the left side of the robot of Figure 17, the analysis of 2

\section{CONCLUSION}

Based on the research that was carried out and explained in the second chapter, it can be seen to have fulfilled the first two conditions 2.2.1 and 2.2.2, which are necessary for the movement. These are: the first is due to the simplicity of the robot control mechanism embedded control leg movements.

The other, which is necessary for movement, and which is necessary to form a sequence of movement (walking gates) of the legs shown in Figure 1 for insect with six legs.

Because of that, this robot can move but is not able to overcome any rough terrain as well as soft surfaces.

The third and fourth condition of which is the ability to adapt to the surface with the help of elastic leg in vertical and horizontal planes is missing.

A lot can be learnt from observing and studying nature. In this case, it is shown that an incomplete set of bionic principles as a solution give a design that is not successful or the results that do not meet our expectations. And the expectation is that the robot can move on uneven surfaces.

If we want for robot to easily move on uneven terrain it is necessary to provide it 2.2.3 and 2.2.4 conditions, elastic displacement in the vertical and horizontal planes of movement.

Software tools that were used in this study are very useful in the process of designing a machine that is inspired by nature.

Nature should be seen as a great library that has deposited knowledge for millions of years,. It should be kept with care.

\section{REFERENCES}

[1] Rašuo, B.: Bionics in Design, University of Belgrade, Faculty of Mechanical Engineering, Belgrade, eBook on CD (in Serbian), 2010.

[2] Nachtigall, W.: Blüchel, KG., Das große Buch der Bionik, Deutsche Verlags-Anstalt, Stuttgart, 2003.

[3] Blüchel, KG.: Malik, F., Faszination Bionik, Faszination Bionik: Die Intelligenz der Schöpfung, Das Erste, St allen, 2006.

[4] Allen R., (Editor): Bulletproof Feathers: How Science Uses Nature's Secrets to Design Cutting-edge Technology, University of Chicago Press, Chicago, 2010.

[5] Rossmann, T., Tropea, C.: Bionik: Aktuelle Forschungsergebnisse in Natur-, Ingenieur- und Geisteswissenschaft, Springer, Berlin, 2005.

[6] Nachtigall, W.: Bionik: Grundlagen und Beispiele für Ingenieure und Naturwissenschaftler, 2 edition, Springer, Berlin, 2002.

[7] Vuković, N., Miljković Z.: New Hybrid Control Architecture for Intelligent Mobile Robot Navigation in a Manufacturing Environment, FME Transactions, Volume 37 No 1, 2009. pp. 9-18.

[8] Holmes, P., et al., Dynamics of legged locomotion: Models, analyses, and challenges. SIAM Review (SIREV) 48 (2), 2006, 207-304.

[9] Schmitt, J., Garcia, M., Razo, R.C., Holmes, P. and Full, R.J.: Dynamics and stability of legged 
locomotion in the horizontal plane: A test case using insects. Bio. Cyber. 86 (5), 2002, 343-353.

[10] Stevanović, I.: Development of a miniature robot the based on experience that is inspired by nature, MSc Thesis, University of Belgrade, Faculty of Mechanical Engineering, Belgrade, (in Serbian), 2011.

[11] Stevanović, I., Rašuo, B.: Development of a miniature robot based on experience that is inspired by nature, $84^{\text {th }}$ Annual Meeting of the International Association of Applied Mathematics and Mechanics (GAMM), Novi Sad, Serbia, 18 - 22 March, 2013, Book of Abstract, page 130.

[12] Stevanović, I., Rašuo, B.: Development of a miniature robot based on experience that is inspired by nature, PAMM, Vol. 13, Issue 1, Dec. 2013, pages 49-50, DOI: 10.1002/pamm.201310020.

\section{РАЗВОЈ МИНИЈАТУРНОГ РОБОТА НА ОСНОВУ ИСКУСТВА КОЈЕ ЈЕ ИНСПИРИСАНО ПРИРОДОМ}

\section{Илија Стевановић, Бошко Рашуо}

У раду су објашњени основни принципи бионике. Користећи основне принципе бионике урађена је анализа кретања биолошких система која се крећу уз помоћ ногу на бази лабораторијских посматрања и мерења у којима су проучена кретања биолошких система који се крећу уз помоћ ногу. Затим је дизајниран ЗД модел робота по угледу на инсекате са шест ногу а применом два од четири основна принципа за кретање уз помоћ ногу. ЗД модел је направљен уз помоћ Solidworks програмског пакета. Математички модел уз помоћ Matlab Simulink SimMechanic Софтвера. Користећи савремене софтверске алате Solidworks и Matlab Simulink извршена je математичка анализа његовог механизма за кретање у 3Д окружењу. Приказано је да је Бионика уз помоћ савременог софтвера може бити моћан инжењерски алат али и да је за потпуне резултате неопходно применити све принципе који су у анализи добијени. 